\title{
Educational Competencies That Mid-Sized CPA Firms Value In Their Professional Accounting Staff
}

Loren Margheim, University of San Diego, USA Judith A. Hora, University of San Diego, USA Diane Pattison, University of San Diego, USA

\begin{abstract}
This study examined the educational competencies mid-sized accounting firm partners value in their professional staff when making promotion decisions to senior, manager, and partner. Midsized firms were defined in this study to include all of the non-Big 4 national firms, the large regional CPA firms, and several large local firms. Over 1,380 partners received two mailings of a survey instrument and usable responses were received from 699 of those partners. The paper summarizes the competencies the respondents indicated were important to be promoted in their firms. In addition, the study summarizes demographic characteristics of those mid-sized accounting firm partners and the advantages they perceive of working for a mid-sized accounting firm. Results indicate that technical accounting skills are very important to mid-sized firms, but that their relative importance decreases as individuals are considered for higher level positions. On the other hand, the importance of communication, leadership, and interpersonal skills grows all the way through the partner promotion decision.
\end{abstract}

Keywords: Educational Competencies, Mid-sized CPA Firms

\section{INTRODUCTION}

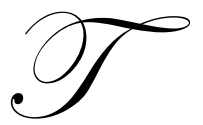

he primary purpose of this study is to examine the educational competencies that partners in midsized accounting firms value in their professional accounting staff when making promotion decisions to senior, manager, and partner levels. Prior research has not examined the educational competencies desired in mid-sized CPA firms. Secondarily, the study examines the demographic characteristics of the professional staff working at mid-sized CPA firms as well as the perceived advantages of working for a midsized CPA firm versus the larger, Big-4 firms.

This research was motivated by the lack of knowledge as to the skills and competencies desired by midsized CPA firms in their professional staff, particularly when promotion decisions are made. Research examining the educational competencies desired by public accounting firms has generally focused on the professional staff of the Big-4 CPA firms. However, the number and influence of mid-sized accounting firms has grown since the consolidation process that led to the Big-4. Mid-sized firms are now engaged in hiring more staff directly out of accounting programs and, in many instances, have their own national training programs for new staff. Further, many of these mid-sized firms have also developed their own internship programs to attract new staff to their firms. However, mid-sized CPA firms often try to differentiate themselves from the Big-4 firms by indicating in their recruiting process that they have different needs and desires when hiring and promoting members of their professional staff. Therefore, knowledge as to what skills and competencies mid-sized accounting firms value when making promotion decisions is clearly needed by the accounting educational community.

Specifically, this study surveyed partners in mid-sized CPA firms. The survey instruments used by Bhamornsir and Guinn (1991), Guinn and Bhamornsiri (2000) and Guinn, Bhamornsiri, and Blanthorne (2004) to 
survey partners in the very large CPA firms on similar issues were modified for use in this study. Specifically, the partners were asked to indicate the educational competencies that they felt were important in their firm to be promoted from staff to senior, from senior to manager, and from manager to partner. They were also asked to indicate their perceptions of the advantages of working for a mid-sized CPA firm and to provide demographic data.

\section{SUBJECTS}

Mid-sized CPA firms were identified from Public Accounting Report's Top 100 Largest Public Accounting Firms. Size was determined by a combination of number of partners and annual revenue. In general, this included all of the non-Big 4 national firms, the large regional CPA firms, and several large local firms. For the purpose of this study this group of accounting firms is being described as "mid-sized" to differentiate them from the large Big-4 firms.

Table 1: Characteristics of Sample

\begin{tabular}{lcc} 
Total Surveys Mailed & & \\
To Mid-sized Partners: & 432 & 1,381 \\
First Mailing Responses: & $\underline{267}$ & \\
Second Mailing Responses: & & 699 \\
Total Usable Responses: & & $50.6 \%$ \\
Response Rate & \\
\hline
\end{tabular}

The AICPA was asked to provide a list of partners at the selected mid-sized firms, and they provided a complete list of 1,381 partners. To acquire the best data possible, all partners identified by the AICPA were sent survey instruments. Therefore, a total of 1,381 survey instruments were mailed to the partners in those mid-sized CPA firms using the AICPA mailing list. As summarized in Table 1, there were two mailings of the survey instrument resulting in a total of 699 usable responses. This represented a response rate of over $50 \%$ of the midsized accounting firm partners who received the survey instrument.

The 699 partner responses were separated based on their area of service. Overall, 298 (43\%) indicated they were assurance/audit partners, $86(12 \%)$ were consulting partners, $271(39 \%)$ were tax partners, and $44(6 \%)$ were classified as other partners. Other partners included administrative partners, those who worked in multiple areas, or those who that did not indicate an area of service.

\section{CHARACTERISTICS OF PARTNER RESPONDENTS}

The demographic characteristics of the study's respondents are shown in Table 2 and are discussed below.

\section{Age}

Overall, the results indicate that $59 \%$ of the respondents became partners before age 36 . Audit and consulting partners lead the way in that $63 \%$ and $64 \%$ of those groups, respectively, becoming partners before age 36. A similar survey of Big 5 firms by Guinn and Bhamornsiri (2000) found that only $41 \%$ of all their respondents became partners before age 36, suggesting that it is easier to become a partner at a younger age in mid-sized CPA firms.

\section{Gender}

Overall, $90 \%$ of the respondents were male and $10 \%$ were female. This breakdown was very similar across all service areas. These results show a slightly higher male percentage than found by Guinn and Bhamornsiri (2000) in their survey of Big 5 partners where $84 \%$ were male and $16 \%$ were female. Therefore, our results suggest that the large, Big-4 accounting firms may have a somewhat higher female partner percentage than do mid-sized firms. Prior research (Whiting and Van Vugt, 2006) does suggest that Big-4 firms are more likely to promote females to partner than non Big-4 firms. However, the results of the current study do not indicate there are large differences in the percentage of male versus female partners in our mid-sized firms than that found in the large firms. 


\section{Ethic Group}

The results of our survey indicated that $98 \%$ of the responding partners in our mid-sized CPA firms were Caucasian. The prior study by Guinn and Bhamornsiri (2000) did not measure this characteristic in the new partners of large firms. This result is somewhat surprising given the efforts of the profession to promote diversity in the CPA profession.

\section{PARTNER CREDENTIALS AND WORK EXPERIENCE}

Table 3 indicates the credentials and the work experience of our respondent partners. The results are discussed below.

\section{Highest Academic Credentials}

Overall, $70 \%$ our respondents held only one bachelor's degree while the other $30 \%$ held two bachelors degree or an advanced degree. For those holding only one bachelor's degree, $84 \%$ had majored in accounting. Of the $30 \%$ holding multiple bachelor's degrees or advanced degrees, half of those ( $15 \%$ of the total responses) held Masters in Accounting or Masters in Taxation.

These results contrast significantly from prior research by Bhamornsir and Guinn (1991) and Guinn and Bhamornsir (2000) which found that $45 \%$ of their large CPA firm respondents had multiple or advanced degrees versus the $30 \%$ from our mid-sized firms. Despite the move toward the 150-hour CPA requirements, these results suggest that mid-sized CPA firms employ significantly fewer partners having advanced degrees than in the larger Big-4 firms. This result suggests that holding an advanced degree is not as important an educational qualification in mid-sized firms than in the Big-4 CPA firms. This result should be reexamined after the 150-hour requirement has matured to see if this difference remains over time.

Examination of the individual service areas indicate that the academic background of the audit, consulting, and other partners are similar. However, tax partners stand out as being significantly different with $43 \%$ having multiple bachelors or advanced degrees and 57\% having only a single bachelor's degree. Of the $43 \%$ having multiple or advanced degree, almost half of that amount (20\%) hold Masters of Taxation degrees and 10\% of that total hold graduate law degrees.

The most recent survey of large firms by Guinn and Bhamornsire (2000) found that $36 \%$ of tax partners in large firms had only one bachelor's degree and $64 \%$ had multiple or advanced degrees. Two differences are suggested when comparing our mid-sized taxation area results to those found in the above survey of larger firms. First, the taxation area is the most likely area to have advanced degree holders in both large and mid-sized firms. Second, the mid-sized CPA firms do not emphasize an advanced tax degree as a qualification for promotion to partner as much as the larger firms since only $43 \%$ of our taxation respondents had multiple or advanced degrees compared to the $64 \%$ found in the Guinn and Bhamornsire (2000) study of larger firms. For those having an advanced degree, the Masters of Taxation or a graduate law degree are favored academic credentials of both larger and mid-sized firms of those being promoted to partner. 
Table 2: Characteristics of Respondents

\begin{tabular}{|c|c|c|c|c|c|}
\hline & $\begin{array}{c}\text { Assurance/Audit } \\
\text { Partners } \\
\text { n=298 } \\
\end{array}$ & $\begin{array}{c}\text { Consulting } \\
\text { Partners } \\
\text { n=86 } \\
\end{array}$ & $\begin{array}{c}\text { Tax } \\
\text { Partners } \\
\mathbf{n}=271 \\
\end{array}$ & $\begin{array}{c}\text { Other } \\
\text { Partners } \\
\text { n=44 }\end{array}$ & $\begin{array}{c}\text { All } \\
\text { Partners } \\
\mathrm{n}=699\end{array}$ \\
\hline \multicolumn{6}{|c|}{ Age They Became Partners: } \\
\hline Under 36 & $63 \%$ & $64 \%$ & $54 \%$ & $57 \%$ & $\mathbf{5 9 \%}$ \\
\hline 36 to 40 & $25 \%$ & $16 \%$ & $32 \%$ & $29 \%$ & $27 \%$ \\
\hline 41 to 45 & $9 \%$ & $8 \%$ & $8 \%$ & $9 \%$ & $9 \%$ \\
\hline \multirow[t]{2}{*}{ Over 45} & $3 \%$ & $12 \%$ & $6 \%$ & $5 \%$ & $\underline{\mathbf{5 \%}}$ \\
\hline & $100 \%$ & $100 \%$ & $100 \%$ & $100 \%$ & $100 \%$ \\
\hline \multicolumn{6}{|l|}{ Gender: } \\
\hline Male & $90 \%$ & $87 \%$ & $90 \%$ & $92 \%$ & $\mathbf{9 0 \%}$ \\
\hline \multirow{2}{*}{ Female } & $10 \%$ & $13 \%$ & $10 \%$ & $\underline{8 \%}$ & $\underline{10 \%}$ \\
\hline & $100 \%$ & $100 \%$ & $\overline{100 \%}$ & $100 \%$ & $\overline{100 \%}$ \\
\hline \multicolumn{6}{|c|}{ Ethnic Group: } \\
\hline Black & $1 \%$ & $0 \%$ & $0 \%$ & $1 \%$ & $1 \%$ \\
\hline Caucasian & $98 \%$ & $100 \%$ & $99 \%$ & $99 \%$ & $\mathbf{9 8 \%}$ \\
\hline \multirow[t]{2}{*}{ Other } & $\underline{1 \%}$ & $\underline{0 \%}$ & $\underline{1 \%}$ & $\underline{0 \%}$ & $\underline{1 \%}$ \\
\hline & $100 \%$ & $100 \%$ & $100 \%$ & $100 \%$ & $\overline{100 \%}$ \\
\hline
\end{tabular}


Table 3: Partner Credentials and Work Experience

\begin{tabular}{|c|c|c|c|c|c|}
\hline & $\begin{array}{l}\text { Assurance/Audit } \\
\text { Partners } \\
\text { n=298 } \\
\end{array}$ & $\begin{array}{c}\text { Consulting } \\
\text { Partners } \\
\text { n=86 } \\
\end{array}$ & $\begin{array}{c}\text { Tax } \\
\text { Partners } \\
\mathbf{n}=\mathbf{2 7 1} \\
\end{array}$ & $\begin{array}{c}\text { Other } \\
\text { Partners } \\
n=44 \\
\end{array}$ & $\begin{array}{c}\text { All } \\
\text { Partners } \\
\mathrm{n}=699 \\
\end{array}$ \\
\hline \multicolumn{6}{|l|}{ Highest Academic Credentials: } \\
\hline Single Bachelor's Degree Total: & $79 \%$ & $75 \%$ & $57 \%$ & $78 \%$ & $70 \%$ \\
\hline Two bachelor's degrees & $4 \%$ & $5 \%$ & $4 \%$ & $3 \%$ & $4 \%$ \\
\hline MBA degree & $4 \%$ & $2 \%$ & $2 \%$ & $3 \%$ & $3 \%$ \\
\hline Master's degree in accounting & $8 \%$ & $7 \%$ & $5 \%$ & $3 \%$ & $7 \%$ \\
\hline Master's degree in taxation & $0 \%$ & $5 \%$ & $20 \%$ & $3 \%$ & $8 \%$ \\
\hline Other master's degree & $4 \%$ & $5 \%$ & $2 \%$ & $5 \%$ & $3 \%$ \\
\hline J.D. with or without LLM & $\underline{1 \%}$ & $\underline{1 \%}$ & $\underline{10 \%}$ & $\underline{5 \%}$ & $\underline{\mathbf{5 \%}}$ \\
\hline \multirow[t]{2}{*}{ Multiple Degrees or Advanced Degree Total: } & $\overline{21 \%}$ & $\underline{25 \%}$ & $\overline{43 \%}$ & $\overline{22 \%}$ & $\overline{\mathbf{3 0 \%}}$ \\
\hline & $100 \%$ & $100 \%$ & $100 \%$ & $100 \%$ & $100 \%$ \\
\hline \multicolumn{6}{|l|}{ Certification: } \\
\hline CPA only & $86 \%$ & $65 \%$ & $77 \%$ & $51 \%$ & $78 \%$ \\
\hline CPA plus one or more other other certifications & $14 \%$ & $31 \%$ & $23 \%$ & $46 \%$ & $21 \%$ \\
\hline \multirow[t]{2}{*}{ No certification or non-CPA certification } & $\underline{0 \%}$ & $\underline{4 \%}$ & $\underline{0 \%}$ & $\underline{3 \%}$ & $\underline{1 \%}$ \\
\hline & $100 \%$ & $100 \%$ & $100 \%$ & $100 \%$ & $\overline{100 \%}$ \\
\hline \multicolumn{6}{|l|}{ Prior Work Experience: } \\
\hline Begin career with current employer & $44.0 \%$ & $37.0 \%$ & $29.0 \%$ & $32.0 \%$ & $36.0 \%$ \\
\hline \multirow[t]{2}{*}{ Begin career with other employers } & $\underline{56.0 \%}$ & $\underline{63.0 \%}$ & $\underline{71.0 \%}$ & $\underline{68.0 \%}$ & $\underline{64.0 \%}$ \\
\hline & $100 \%$ & $100 \%$ & $100 \%$ & $100 \%$ & $\overline{100 \%}$ \\
\hline \multicolumn{6}{|l|}{$\begin{array}{l}\text { Of those that began career with other employers, } \\
\text { who was their immediate prior employer: }\end{array}$} \\
\hline Public accounting firm & $89 \%$ & $79 \%$ & $85 \%$ & $64 \%$ & $84 \%$ \\
\hline \multirow[t]{2}{*}{ Non-public accounting firm or company } & $\underline{11 \%}$ & $\underline{21 \%}$ & $\underline{15 \%}$ & $\underline{36 \%}$ & $16 \%$ \\
\hline & $\overline{100 \%}$ & $\overline{100 \%}$ & $\overline{100 \%}$ & $\overline{100 \%}$ & $\overline{100 \%}$ \\
\hline \multicolumn{6}{|c|}{$\begin{array}{l}\text { Of those that began career with other employers, } \\
\text { what was their initial appointment with their current firm: }\end{array}$} \\
\hline Staff & $14 \%$ & $18 \%$ & $14 \%$ & $24 \%$ & $15 \%$ \\
\hline Senior & $25 \%$ & $18 \%$ & $16 \%$ & $16 \%$ & $20 \%$ \\
\hline Manager & $24 \%$ & $25 \%$ & $36 \%$ & $32 \%$ & $30 \%$ \\
\hline \multirow{2}{*}{ Partner } & $\underline{37 \%}$ & $\underline{39 \%}$ & $\underline{34 \%}$ & $\underline{28 \%}$ & $35 \%$ \\
\hline & $100 \%$ & $100 \%$ & $100 \%$ & $100 \%$ & $\overline{100 \%}$ \\
\hline
\end{tabular}




\section{Certification}

The results indicate that $98 \%$ of our respondents had a CPA certificate. Of that total percentage, $21 \%$ had additional certifications. Clearly, having a CPA certificate is a critical criteria for being promoted to partner in a mid-sized CPA firm. The results of the survey of large firms by Guinn and Bhamornsire (2000) found that $71 \%$ of their respondent partners at the large firms had a CPA certificate or other certification.

The differences in results may indicate that the large firms have the capacity to promote a significant number of non-CPAs to consulting partnerships, while mid-sized firms really have to emphasize having a CPA certificate in almost all of their partner promotion decisions. The Guinn and Bhamornsire (2000) results support this explanation in that they found $89 \%$ or more of their audit and tax partners had CPA certificates while only $32 \%$ of their consulting partners had CPA certificates versus $96 \%$ of our mid-sized consulting partners.

\section{Prior Work Experience}

Our results indicate that only $36 \%$ of our mid-sized partners started their career with their current firm. This contrasts to the results of the Guinn and Bhamornsire (2000) study that found 57\% of their large firm partners started their career with their current firm. This suggests that mid-sized firms hired more experienced personnel that ultimately become partners than is the norm in the larger Big-4 accounting firms.

Our survey also examined the previous work experience of our partner respondents and their original level of hire. The results show that $84 \%$ of those hired with previous experience came from other public accounting positions while only $16 \%$ came from non-public accounting positions. In addition, the results show that $65 \%$ of the experienced hires came into their current firm as either managers or partners.

Overall, these results suggest several things about the road to promotion in mid- sized firms. First, unlike large firms, a large majority of those who became partners in mid-sized firms started their career in another organization. Second, the individuals most likely worked for another public accounting firm before joining their current mid-sized firm. Finally, the individuals were likely hired at a more advanced stage of their career, most likely joining the mid-sized firm as either a manager or partner.

These results seem to implicitly suggest that many managers and partners at large CPA firms make the decision to move to mid-sized firms where advanced level hires appear to be common. In essence, the road to partnership in a mid-sized accounting firm for a majority of our respondents appears to actually begin with initial employment at another public accounting firm.

\section{Competencies Important for Promotion}

Our study's respondents were asked to indicate, using 5-point Likert scales, the importance of six skill sets in each of the following three promotion decisions:

1. staff to senior,

2. senior to manager, and

3. manager to partner.

Individual scores ranged from a one indicating not important, up to a five indicating very important. The six skills sets defined by Guinn and Bhamornsiri (2000) to examine similar promotions in large accounting firms were adopted and used in this study examining mid-sized firms and include the following:

1. Technical competence skills,

2. Communication skills,

3. Leadership skills,

4. Interpersonal skills,

5. Administrative skills,

6. Practice development skills 
The mean scores for all partners and for partners in the audit, consulting, and taxation service areas are shown in Table 4. The Table shows the mean scores along with the relative ranking of the skill sets versus the other skill sets examined.

Table 4: Capabilities for Promotion

\begin{tabular}{|c|c|c|c|c|c|c|}
\hline & \multicolumn{2}{|c|}{ Staff to Senior } & \multicolumn{2}{|c|}{ Senior to Manager } & \multicolumn{2}{|c|}{ Manager to Partner } \\
\hline & Rank* & Mean** & Rank* & Mean** & Rank* & Mean** \\
\hline \multicolumn{7}{|l|}{ Assurance/Audit Partners } \\
\hline Technical competence & 1 & 4.47 & 1 & 4.57 & 5 & 4.27 \\
\hline Communication skills & 2 & 4.11 & 2 & 4.45 & 2 & 4.67 \\
\hline Leadership skills & 4 & 3.33 & 4 & 4.19 & 1 & 4.71 \\
\hline Interpersonal skills & 3 & 3.83 & 3 & 4.25 & 3 & 4.59 \\
\hline Administrative skills & 5 & 2.70 & 5 & 3.40 & 6 & 3.84 \\
\hline Practice development & 6 & 1.95 & 6 & 3.16 & 4 & 4.51 \\
\hline \multicolumn{7}{|l|}{ Consulting Partners } \\
\hline Technical competence & 1 & 4.47 & 2 & 4.42 & 5 & 4.09 \\
\hline Communication skills & 2 & 4.18 & 1 & 4.45 & 1 & 4.79 \\
\hline Leadership skills & 4 & 3.35 & 4 & 4.22 & 2 & 4.76 \\
\hline Interpersonal skills & 3 & 4.01 & 3 & 4.25 & 3 & 4.75 \\
\hline Administrative skills & 5 & 2.77 & 5 & 3.48 & 6 & 3.91 \\
\hline Practice development & 6 & 2.54 & 6 & 3.43 & 4 & 4.72 \\
\hline \multicolumn{7}{|l|}{ Tax Partners } \\
\hline Technical competence & 1 & 4.54 & 1 & 4.56 & 5 & 4.40 \\
\hline Communication skills & 2 & 4.11 & 2 & 4.41 & 1 & 4.65 \\
\hline Leadership skills & 4 & 3.32 & 4 & 4.02 & 2 & 4.55 \\
\hline Interpersonal skills & 3 & 3.89 & 3 & 4.16 & 3 & 4.46 \\
\hline Administrative skills & 5 & 2.71 & 6 & 3.31 & 6 & 3.83 \\
\hline Practice development & 6 & 2.38 & 5 & 3.34 & 4 & 4.45 \\
\hline \multicolumn{7}{|l|}{ All Partners } \\
\hline Technical competence & 1 & 4.50 & 1 & 4.55 & 5 & 4.30 \\
\hline Communication skills & 2 & 4.12 & 2 & 4.44 & 1 & 4.68 \\
\hline Leadership skills & 4 & 3.32 & 4 & 4.13 & 2 & 4.66 \\
\hline Interpersonal skills & 3 & 3.88 & 3 & 4.21 & 3 & 4.56 \\
\hline Administrative skills & 5 & 2.71 & 5 & 3.36 & 6 & 3.84 \\
\hline Practice development & 6 & 2.20 & 6 & 3.27 & 4 & 4.51 \\
\hline \multicolumn{7}{|c|}{$\begin{array}{l}\text { * Ranking is based on the mean scores } \\
\text { ** Mean scores are based on the response scale of } 1=\text { not important and } 5=\text { very important. } \\
\text { The mean scores are based on the varying numbers of responses because each } \\
\text { respondent did not necessarily work at each of the three employment levels. }\end{array}$} \\
\hline
\end{tabular}

\section{Technical Competence Skills}

Overall, partners in our mid-sized firms gave technical competence skills very high importance scores for each of the three promotion decisions. Overall, technical competence skills had a mean importance score of 4.50 (out of 5.00) for the staff to senior promotion, 4.55 for the senior to manager promotion, and 4.30 for the manager to partner promotion. Converting the mean importance scores to relative rankings reveals that technical competence was ranked the most important for the staff to senior promotion and the senior to manager promotion. However, despite its high 4.30 mean score for the manager to partner promotion, the overall importance of technical competence dropped to fifth place in importance for this promotion decision.

Examination of the technical competence mean scores for the individual service area reveals almost identical results. As shown in Table 4, mean importance scores were 4.00 for all area promotions examined for audit, consulting and tax partners. Similar to the overall results for all partners, technical competence was ranked as one of the most important skill sets in the staff to senior and the senior to manager promotion decision, but mean scores dropped slightly and its ranking dropped down to fifth place in the manager to partner promotion decision. 
These results of our study suggests that technical competence is an extremely important skill set that a newly hired staff accountant will need if hired by a mid-sized CPA firm. Further, the development of their technical expertise will be one of the most important skills needed if a member of the professional staff expects to be promoted to senior and then a manager. However, other skill sets seem to take precedence during the promotion to partner decision. These results for mid-sized firms are very similar to those reported by Guinn and Bhamornsiri (2000) when they examined the importance of technical skills in promotions in large public accounting firms.

\section{Communication Skills}

Overall, the partners gave communication skills a mean importance score of 4.12 for the staff to senior promotion, 4.44 for the senior to manager promotion, and 4.68 for the manager to partner promotion. Unlike technical competence skills, the overall mean importance for communication skills increased for each promotion decision. These skills were ranked second in importance (behind technical competence skills) for the staff to senior promotion and the senior to manager promotion. However, the ranking of this skill set jumped to the top spot in the manager to partner promotion decision.

These results suggest that communication skills will be very important to individuals accepting positions in mid-sized accounting firms and that the importance of this skill set will grow all the way through the partner promotion decision. As with the technical competence skill set, these results are very similar to those found by Guinn and Bhamornsiri (2000) when examining promotions in large public accounting firms.

\section{Leadership Skills}

Overall, the partners gave leadership skills a mean importance score of 3.32 for staff to senior promotion, 4.13 for the senior to manager promotion, and 4.66 for the manager to partner promotion. Similar to the communication skill set, the mean scores increased all the way through the partner decision. Leadership skills were ranked fourth in importance for the staff to senior promotion decision and in the senior to manager promotion decision. However, similar to the communication skill set, its importance moved up to rank second in importance in the manager to partner promotion decision. In fact, the difference in means between communication skills and leadership skills were not statistically different, indicating that these two skill sets are approximately equal in importance in the manager to partner decision. Again, examination of the individual service areas provides results that are also identical to the overall results discuss above.

Like communication skills, these results suggest that leadership skills will grow in importance for an individual all the way through the partner promotion decision. In fact, a careful examination of the means in Table 4 shows that the mean importance of leadership skills jumped by .53 (4.13 to 4.66) from the senior to manager promotion to the manger to partner promotion. These results suggest that a manager desiring promotion in a midsized firm needs to ensure they have developed their leadership skill set.

\section{Interpersonal Skills}

Overall, the partners gave interpersonal skills a mean importance score of 3.88 for staff to senior promotion, 4.21 for the senior to manager promotion, and 4.56 for the manager to partner promotion. These means resulted in interpersonal skills being ranked third in all promotion decision. The means and ranking are similar for all the individual service areas. Unlike the technical competence skill, communication skills, and leadership skills discussed above, the relative importance of interpersonal skills versus the other skill sets examined does not change for the manager to partner promotion decision. Interpersonal skills are, therefore, a relatively important set of skills needed for any promotion in our mid-sized firms.

\section{Administrative Skills}

Overall, the partners gave administrative skills a mean importance score of 2.71 for staff to senior promotion, 3.36 for the senior to manager promotion, and 3.84 for the manager to partner promotion. These means put administrative skills in either the fifth or sixth ranking positions. These means are relatively consistent across all 
the individual service areas. In addition, they are consistent with those found in large accounting firms (Guinn and Bhamornsiri, 2000). Overall, it appears that while administrative skills are needed, mid-sized firms do not appear to value these skills very highly when making promotion decisions at any level.

\section{Practice Development Skills}

Overall, the partners gave practice development skills a mean importance score of 2.20 for staff to senior promotion, 3.27 for the senior to manager promotion, and 4.51 for the manager to partner promotion. These means resulted in a sixth place ranking for these skills in the staff to senior and the senior to manager promotion decision. However, the importance of these skills did jump to the fourth place position in the manager to partner promotion decision. These ranking are similar across all individual service area and also are very similar to those found in surveys of partners in large accounting firms (Guinn and Bhamornsiri, 2000).

\section{PERCEIVED ADVANTAGES FOR WORKING IN A NON-BIG 4 ENVIRONMENT}

The responding partners were asked to indicate their perceived advantages for working in a Non-Big 4 public accounting environment. The survey provided a list of potential reasons and a blank for additional reasons. The responding partners were asked to select up to three advantages. The list of potential reasons was developed through discussions with several partners working in mid-sized accounting firms when the survey instrument was being developed.

Table 5 contains the key advantages noted by our respondents. There appears to be a broad consensus of the partners surveyed on two key advantages of working in a mid-sized firm versus a larger Big-4 firm:

1. $\quad$ More personal client relationships, and

2. More personal work environment.

Table 5: Advantages of Working in a Non-Big 4 Public Accounting Firm

\begin{tabular}{lcc}
\hline & Responses & Percentage of Respondents* \\
\hline More personal client relationships & 615 & $88 \%$ \\
More personal work environment & 501 & $72 \%$ \\
Less travel & 268 & $38 \%$ \\
More flexible hours & 147 & $21 \%$ \\
Less stressful environment & 146 & $21 \%$ \\
Less overtime & 30 & $4 \%$ \\
\hline
\end{tabular}

*Respondents were asked to select up to three advantages of working in a non-Big 4 public accounting firm. The percentages in this Table indicate the relative number of our respondents that selected the indicated items as part of their relative advantages.

Less travel was cited by $38 \%$ of the respondents while more flexible hours and less stressful environment were each cited by approximately $21 \%$ of the respondents. These results suggest these two potential advantages (i.e., more flexible hours and less stressful environment) are important to a segment of partners in mid-sized firms, but that a large majority of our responding partners did not perceive these to be key reasons to join a mid-sized accounting firm over a larger Big-4 accounting firm.

Finally, less overtime received was only cited by $4 \%$ of our responding partners as a key advantage to joining a mid-sized firm. This is an interesting result in that many students perceive that less overtime would be one of the main reasons they might join a mid-sized firm. However, the results of this study suggest that individuals working for mid-sized firms apparently do not feel they have less overtime than their colleagues at the large Big-4 CPA firms. 


\section{0-HOUR RULE AND PROGRESS TOWARD PARTNERSHIP}

Finally, the partners were asked to indicate their perceptions of the importance of having the extra 30 semester hours required by the 150-hour rule to become a CPA in most states. The results are shown in Table 6Panel A and show a clear split in the opinions of our respondents. A total of $51 \%$ of our mid-sized partners indicated that the extra 30 hours was not important in developing skills that are essential for progressing to partner in their firm. On the other hand, $49 \%$ of the partners indicated that the extra hours were either somewhat important $(37 \%)$ or were very important (12\%) in developing essential skills.

The Guinn and Bhamornsir (2000) survey of larger firm partners found that less than $25 \%$ of their respondents felt that education beyond 120 semester hours was important for promotion to partner. The higher percentage of our respondents that perceived at least some importance to the additional semester hours (i.e., 49\%) might be due to a difference in attitudes of the partners in mid-sized firms or to a change in attitude of those in the profession during the years since the partners in the larger firms were surveyed. In either case, there does not appear to be any consensus as to the importance of the 150-hour requirement in providing important skills in the progression toward partnership.

The partners were asked to follow up by indicating what topics should be taught in the additional 30 hours required under the 150-hour rule. The partners were provided a list of potential topics and were asked to rank them in importance from one (most important) to six (least important). The average rankings are shown in Table 6-Panel $\mathrm{B}$ and indicate that communication topics was clearly selected as the most important topic to be included in the additional 30 semester hours. This is consistent with the results of the Guinn and Bhamornsir (2000) study which found that large firm partners also ranked communication topics as the most important to be included in the additional 30 hours.

Communication topics was followed by marketing and management topics in the second and third positions, respectively. This suggest that our mid-sized partners believed that acquiring broad business skills should be important topics provided in the additional 30 hours. This contrasts sharply with the results of the Guinn and Bhamornsir (2000) study where the large firm partners ranked marketing and management skills near the bottom of the recommended skills needed in the extra 30 hours.

Accounting topics, information technology, and computer and system topic were ranked by our partners as the least important skills, respectively, that needed to be included in the extra 30 hours. These results also contrast with those found in the survey of the larger firm partners where information technology and computer and system skills were ranked second and third in importance, just behind communication skills. These results might suggest that the work in mid-sized firms may require giving more managerial advice to clients and might contain less sophisticated accounting systems work than might be found in the clients of the large Big-4 accounting firms.

Table 6: The 150-Hour Rule and Progression Toward Partnership

\begin{tabular}{lc}
\hline Panel A : Overall Importance of having the extra 30 semester hours required by the 150-hour rule to become a CPA: \\
\hline Not Important & $51 \%$ \\
Somewhat Important & $37 \%$ \\
Very Important & $12 \%$ \\
\hline Panel B: Importance of Topics to Included in the Extra 30 Hours:
\end{tabular}

Panel B: Importance of Topics to Included in the Extra 30 Hours:

\begin{tabular}{lc}
\hline & Average Ranking* \\
\hline Communications Topics & 2.62 \\
Marketing Topics & 3.33 \\
Management Topics & 3.49 \\
Accounting Topics & 3.59 \\
Information Technology Topics & 3.68 \\
Computer and System Topics & 3.91 \\
\hline *Respondents were asked to rank the importance of each topic for inclusion in the extra 30 hours of coursework that would \\
maximize the professional success of a hypothetical new partner where 1=most important to 6=least important.
\end{tabular}




\section{SUMMARY AND CONCLUSIONS}

The key conclusions of this study related to the demographics of the professional staff in mid-sized accounting firms, the competencies needed for promotion in those firms, and the advantages of working for midsized accounting firms are summarized below.

\section{Demographics of Professional Staff Summary}

Some of the key findings of this study include:

1. A large percentage (59\%) of responding partners indicted they became partners prior to the age of 36 . This percentage is higher than prior research has found in large CPA firms suggesting mid-sized firms promote individuals to partners at younger ages.

2. Only $30 \%$ of our mid-sized firm partner respondents held multiple or advanced degrees. This is a smaller percentage than prior studies have found in large CPA firms. This suggests that holding an advanced degree may not be as important to promotion in mid-sized CPA firms as it is in the large firms.

3. Tax partners are more likely to have multiple or advanced degrees in mid-sized CPA firms. This is consistent with that found in large CPA firms and suggests that the added technical tax knowledge acquired in graduate programs is important to promotion in mid-sized firms for the professional tax staff.

4. A CPA certificate was held by $98 \%$ of our responding partners. This contrasts to $71 \%$ that was found in prior research in large CPA firms. This result suggests that being certified is more critical to being promoted to partner in a mid-sized firm than it is in a large Big-4 CPA firm.

5. A large percentage of our responding partners were hired directly into their current mid-sized firm as either a manager or partner after having worked for another firm. This suggests that mid-sized firms are comfortable hiring a significant amount of their professional staff directly into more senior level positions.

\section{Competencies for Promotion Summary}

Some of the key finding of this study that relate to the competencies individuals will need to be promoted in mid-sized accounting firms include the following:

1. Technical skills are critical skills needed for promotion to senior, manager, and partner positions in these firms. However, technical skills fall in relative importance in the partner promotion decision and rank below softer skills (e.g., communication, interpersonal, leadership, and practice development skills).

2. Communication skills are very important for individuals desiring promotion in mid-sized CPA firms, and the importance of those skills grows all the way through the partner promotion decision where they were ranked as the most important skill.

3. Leadership and interpersonal skills are also very important in mid-sized CPA firms and, similar to the communication skills, their overall importance grows as the promotion to partner decision approaches.

\section{Advantages of Working for a Mid-sized CPA firm and Reactions to the 150-Hour Requirement Summary}

This study revealed that there is a broad consensus among the responding partners as to two key advantages of working in a mid-sized CPA firm versus a larger Big-4 firm. Specifically, the respondents indicated that working for a mid-sized CPA firm produced more personal client relationships and a more personal work environment. However, relatively few of the respondents perceived that there was less overtime or there was a less stressful work environment in mid-sized CPA firms. This contrasts to what many undergraduate accounting students are often lead to believe during the staff recruiting process.

Finally, 49\% of our responding partners believed that requiring an additional 30 hours of education to complete the 150 -hour requirement was at least to some extent important while $51 \%$ believe the extra education was not that important. It would be of interest to revisit this issue with partners of mid-sized firms in the future to see if their perceptions change as the 150-hour requirement matures. However, the responding partners did seem to agree that teaching communication skills should be a critical component of any extra educational requirements. This 
finding is very consistent with the results of the study that show the importance of communication skills growing throughout the career of a partner in a mid-sized CPA firm.

\section{AUTHOR INFORMATION}

Loren Margheim, Professor of Accountancy, joined the University of San Diego in 1984. Dr. Margheim's specialties are in corporate financial reporting and auditing. His research has generally focused on factors affecting the behavior of auditors while performing audits. Specifically, he has performed research that has identified factors that cause auditors to engage in dysfunctional behaviors during their audits. He has also extensively examined how the work performed by a corporation's internal auditors affects the work of their external CPA's. His research papers have appeared in such journals as Journal of Accounting Research, Advances in Accounting, Auditing: A Journal of Theory and Practice, and Accounting Horizons.

Judith Hora is an Associate Professor of Accountancy at the University of San Diego where she teaches financial accounting in the undergraduate program and financial and international accounting in the graduate programs. Her research focuses on international accounting in capital markets and has been published in a number of academic journals. She has published articles in numerous publications including: Journal of College Teaching \& Learning, Global Perspectives on Accounting Education, and Journal of International Accounting, Auditing and Taxation.

Diane D. Pattison, Professor of Accountancy, joined the University of San Diego faculty in 1986. Professor Pattison has taught at Arizona State University. She has also been a visiting professor at Bocconi University in Milan, Italy. Dr. Pattison's major contribution to the School of Business Administration has been the development of a strong interactive relationship between the professional accounting community and the accounting area. In addition, she has enhanced the undergraduate accountancy program both through effective teaching and by encouraging growth and understanding through advising both the Accounting Society and Beta Alpha Psi. Dr. Pattison has published many articles in Management Accounting, presented papers at a variety of conferences, won the best paper award at the 1995 Western Decision Sciences Conference and the Lybrand Silver Medal for an article in Management Accounting.

\section{REFERENCES}

1. Bhamornsiri S, and Guinn, R.E., (1991) The Road to Partnership in the "Big Six" Firms: Implications for Accounting Education. Issues in Accounting Education, 6(1), pp 9-24.

2. Guinn, R.E., Bhamornsiri, S., and Blanthorne, C. (2004) Promotion to Partner in Big Firms: Truth and Trends. The CPA Journal, 74(4), pp 55-55.

3. Guinn, R.E., and Bhamornsire S. (2000) The Road to Partnership in the "Big 5" Firms-- A Revisit. Paper Presented at the American Accounting Association Annual Meeting, Philadelphia, August 2000.

4. Whiting, R. and Van Vugt, O. (2006) Effect of Gender, Family Structure and Firm Affiliation, on Career Promotion in Auditing. Paper Presented at AFAANZ Conference, Wellington, July 2006. 